\title{
The distribution and biochemical composition of biogenic particles across the subtropical Front in June 1993 (Azores-Madeira region, Northeast Atlantic)*
}

\author{
LUIGI VEZZULLI, PAOLO POVERO and MAURO FABIANO \\ Dipartimento per lo Studio del Territorio e delle sue Risorse (DIP.TE.RIS), University of Genoa, Corso Europa, 26, \\ 16132 Genoa, Italy. E-mail: vezzulli@ dipteris.unige.it
}

\begin{abstract}
SUMMARY: Water samples were collected in the north-east Atlantic Ocean between the Azores and Madeira $\left(33^{\circ} \mathrm{N}-36^{\circ} \mathrm{N}\right.$ and $24^{\circ} \mathrm{W}-26^{\circ} \mathrm{W}$ ) during the Oceanographic Cruise SEMAPHORE in June 1993. Temperature, salinity, nutrients (nitrate and phosphate) and particulate organic matter (organic carbon, organic nitrogen, carbohydrates, proteins and phytopigment) were investigated in the water column to a depth of $2000 \mathrm{~m}$. The presence of the subtropical front (STF) separating warmer more saline Western Atlantic Water (WAW) from colder and fresher Eastern Atlantic Water (EAW) in the upper $100 \mathrm{~m}$, and a tongue of salt water arising from the influence of Mediterranean Water (MW) at a depth of $1000 \mathrm{~m}$, were well identified by the physical and chemical parameters. POC and PON concentrations, in the surface layer $(0-100 \mathrm{~m})$, ranged

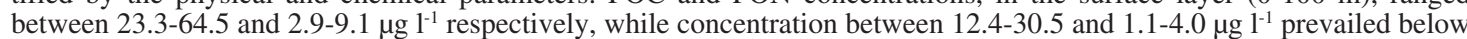
the thermocline $(100-2000 \mathrm{~m})$. The very low POC and PON concentrations together with the low nutrient and chlorophylla concentrations confirmed the oligotrophic nature of the Azores-Madeira region. Statistical analysis was carried out to investigate the difference in the quantity and quality of POM between water masses. Regression analysis showed a high correlation between POC and PON but the slopes and intercepts of the regression lines did not differ significantly between WAW and EAW. In contrast, an examination of vertical profiles as well as mean integrated values of biochemical variables in the upper $100 \mathrm{~m}$ suggest a difference in the quantity and quality of biogenic particles between the water masses. WAW showed the lowest integrated concentrations of particulate organic carbon, particulate organic nitrogen, particulate protein and particulate carbohydrate. In contrast, frontal stations showed the highest values while EAW stations showed intermediate values. All these results, coupled with the occurrence of the highest POC:Chl-a ratio in EAW, suggest a temporal offset in the production cycle between the two water masses. Alternatively, the WAW is a more stratified and oligotrophic body of water than is EAW, and it always has lower biomass and nutrients than the more productive EAW. High chlorophyll-a concentrations were linked to the STF; moreover the average depth of the subsurface chlorophyll maximum (DCM) appeared to shift to shallower values at the frontal stations, suggesting a close association between the STF-Azores Current (AC) physical structure and the distribution of chlorophyll-a in this area.
\end{abstract}

Key words: Subtropical Front; Particulate Organic Matter; North Atlantic Ocean.

RESUMEN: DisTRIBUCIÓN Y COMPOSICIÓN BIOQUÍMICA DE PARTíCULAS BIOGÉNICAS A TRAVÉS DEL FRENTE SUBTROPICAL DURANTE Junio De 1993 (REgión de Azores-Madeira, AtLÁntico Nor-Oriental). - Se recogieron muestras de agua del Océano Atlántico Nor-Oriental entre Azores y Madeira $\left(33^{\circ} \mathrm{N}-26^{\circ} \mathrm{N}\right.$ y $\left.24^{\circ} \mathrm{W}-26^{\circ} \mathrm{W}\right)$ durante la Campaña Oceanográfica SEMAPHORE en Junio de 1993. Se determinó la temperatura, salinidad, nutrientes (nitrato y fosfato) y materia orgánica particulada (carbono y nitrógeno orgánicos, carbohidratos, proteínas y fitopigmentos) en la columna de agua hasta una profundidad de $2000 \mathrm{~m}$. La presencia de un Frente Subtropical (STF) que separaba aguas occidentales Atlánticas (WAW) más templadas y salinas de aguas Atlánticas orientales (EAW) más frías por encima de los $100 \mathrm{~m}$, y la aparición de una lengua de agua más salada debida la influencia de aguas del Mediterráneo (MW) a la profundidad de $1000 \mathrm{~m}$ eran identificadas por parámetros físicos y químicos. Las concentraciones de POC (carbono orgánico particulado) y PON (nitrógeno orgánico particulado) en la capa superficial (0-100 m) oscilaban, respectivamente, entre 23.3-64.5 y 2.9-9.1 $\mu \mathrm{g} \mathrm{l}^{-1}$, mientras que concentraciones entre 12.4-30.5 y 1.1-4.0 $\mathrm{\mu g}^{\mathrm{l}^{-1}}$ son las que prevalecían a profundidades por debajo de la termoclina $(100-2000 \mathrm{~m})$.

*Received June 25, 2001. Accepted January 21, 2002. 
Las bajas concentraciones de POC y PON junto con las bajas concentración de nutrientes y clorofila-a, confirmaban el carácter oligotrófico de la región Azores-Madeira. El análisis estadístico fue llevado a cabo para investigar las diferencias en cantidad y calidad de la POM (materia orgánica particulada) entre masas de agua. El análisis de regresión mostraba una alta correlación entre POC y PON pero las pendientes y los interceptos de las rectas de regresión no diferían significativamente entre WAW y EAW. Sin embargo, si se examinaban los perfiles verticales así como los valores medios integrados de las variables bioquímicas por encima de los $100 \mathrm{~m}$ se percibía una cierta diferencia en la cantidad y calidad de las partículas biogénicas entre las masas de agua. Las aguas occidentales Atlánticas (WAW) mostraban valores de concentraciones integrados más bajos en carbono orgánico particulado, nitrógeno orgánico particulado, proteínas y carbohidartos particulados. En cambio las estaciones del Frente presentaban los valores más elevados, mientras que las estaciones de EAW mostraban valores intermedios. Todos estos resultados, ligan con el hecho de la aparición de los cocientes POC:chl a más elevados en las aguas Atlánticas orientales (EAW), lo que sugiere una compensación en el ciclo de producción entre las dos masas de agua. Alternativamente, las WAW constituyen una masa de agua más estratificada y oligotrófica que las de EAW y siempre con menor biomasa y nutrientes que las EAW más productivas. Las altas concentraciones de clorofila-a estaban ligadas al STF; además la profundidad media de la capa subsuperficial del máximo de clorofila (SCM) cambiaba a valores menos profundos en las estaciones del frente, indicando una estrecha asociación entre la estructura física de STF- corriente de Azores y la distribución de la clorofila-a en dicha área.

Palabras clave: Frente Subtropical, materia orgánica particulada, Océano Atlántico Nor-Oriental.

\section{INTRODUCTION}

Frontal systems are hydrodynamic features that separate water masses with different thermohaline characteristics and in which the spatial-temporal scales at which physical forces operate are in resonance with the scale relevant for biological processes (Legendre et al., 1986).

Previous studies suggest increased chlorophyll concentrations and pelagic primary production in such areas (Riegman et al. 1990, Heilmann et al. 1994) as well as changes in pelagic community structure (Lindley and Williams, 1994). Extensive work on the coupling between physics and biology in frontal systems has been carried out in coastal marine environments (e.g. Houghton and Marra, 1983; Holligan et al., 1984; Kiorboe et al., 1988) and also in oceanic fronts associated with the Gulf Stream (e.g. Hitchcock et al., 1993; Lohrenz et al., 1993). Among large-scale fronts, subtropical fronts are important both because of their large spatial extent and temporal persistence and because jet-like flows associated with them (Sverdrup et al., 1942) are known to generate highly dynamic systems where strong biological responses are likely to occur (Fasham et al., 1985; Pak et al., 1988).

Particulate organic matter (POM) is of considerable biogeochemical and oceanographic importance, representing a carrier for transport of chemical elements from surface waters of the ocean to the sediments. POM distribution may be affected by local input and transport via gravitational settling, advection, diffusion as well as resuspension from bottom sediments (Fabiano et al., 1993).

Most biogenic particles originate in the ocean photic layer (Eppley and Peterson, 1979). Variations in POM composition can arise from a number of factors, including phytoplankton populations with varying constituent ratios (Fichez, 1991; Navarro et al., 1993; Fabiano et al., 1998). Particle settling through the water column is coupled with biochemical changes and nutrient enrichment of the deep waters (Angel, 1989; Fabiano et al., 1998-2000). The labile fraction of POM, mostly derived from phytoplankton, is composed essentially of proteins, carbohydrates and lipids (Poulet et al., 1986; Fabiano et al., 1993).

The particulate organic matter of the Atlantic Ocean waters was studied in the 1960's (e.g. Wankergsky and Gordon, 1965; Menzel, 1967; Gordon, 1970) and there has been growing interest in recent years due to its importance for the study and the understanding of global biogeochemical cycles (e.g. Jahnke, 1996; Boyd and Newton, 1999; Körtzinger et al., 2001).

In the present study the biochemical composition and spatial distribution of POM were investigated across the subtropical front (STF) southwest of the Azores. The STF separate warmer more saline Western Atlantic Water (WAW) from colder and fresher Eastern Atlantic Water (EAW).

Previous investigations carried out in this area found a link between the presence of the STF and the quantity and quality of POM in the different water masses. Fernandez et al. (1996) in March 1992 observed a coupling between the STF-AC physical feature and high levels of chlorophyll-a. Primary production rates measured in the frontal high chlorophyll region ( $>1 \mathrm{mg} \mathrm{C} \mathrm{m}^{-3} \mathrm{~h}^{-1}$ ) were much higher than previous measurements carried out in the same area in late spring and summer and about 2-times higher than modelling estimates for the region (Fernandez and Pingree, 1996). Later in the season (April-May 1981), Fasham et al. (1985) observed the presence of a well established deep chlorophyll maximum (DCM) but little evidence 
was found for an increased phytoplankton biomass associated with the front. In the same work, the DCM in WAW was on average $20 \mathrm{~m}$ deeper and between $50 \%$ and $60 \%$ of the magnitude of that in EAW. This was explained by the authors by assuming an overall lower level of nutrients and primary productivity in WAW (Fasham et al., 1985).

The aims of this research were: (i) to investigate the location and spatial extension of the subtropical front in June 1993, (ii) to describe the biochemical composition and spatial distribution of POM across the STF in the Azores Madeira region, and (iii) to study the association between the STF-AC physical structure and the biological processes occurring in the area.

\section{MATERIAL AND METHODS}

\section{Area description and sampling}

During summer 1993 an oceanographic cruise took place within the experimental framework of the 'Structure des Echanges Mer-Atmosphere, Properties des Heterogeneites Oceaniques: Recherche Experimentale' (SEMAPHORE), from $22^{\text {st }}$ June to $4^{\text {th }} \mathrm{July}$, in the northern Canary Basin. The water circulation in this region is well studied (Sy, 1988; Pollard et al., 1996; Castro et al., 1998). The Azores Current (AC) is the south-east extension of the Gulf Stream (Gould, 1985). This current joins together with the Portugal Current to the south and then becomes part of the North Equatorial Current that flows to the west (Kase and Siedler, 1982). Gould (1985) maintains that the thermohaline Azores Front observed by Kase and Siedler (1982) is limited in the south by Mediterranean waters; in our study region, the influence of the Mediterranean zone is important. The mixed layer is maximum $(\sim 200 \mathrm{~m}$ depth) in winter and minimum ( 50 m depth) in summer (Levitus, 1982). Below this layer, the North Atlantic Central Water (NACW) occurs at 500-600 $\mathrm{m}, \mathrm{NACW}$ is underlain by intermediate waters (Worthington, 1976; Kase et al., 1985) with the Mediterranean waters, characterised by higher temperature and salinity between $\sim 800-1300 \mathrm{~m}$. Middle NADW occurs at $2000 \mathrm{~m}$ depth and below $3000 \mathrm{~m}$ there is the Lower NADW that arises from the mixing of the waters of the Norwegian Sea and the Denmark Strait (Kawase and Sarmiento, 1986).

During June 1993, twelve stations were sampled between $33^{\circ} \mathrm{N}-36^{\circ} \mathrm{N}$ and $24^{\circ} \mathrm{W}-26^{\circ} \mathrm{W}$ (Fig. 1) on board the R/V Alliance (SACLANTCEN, La Spezia, Italy). Water sampling was carried out by means of 10-liter Niskin bottles assembled in a rosette-sampler or mounted on hydrographic wire. In the upper $2000 \mathrm{~m}$, nominal sampling depths were: the surface (conventionally indicated from now on: $0 \mathrm{~m}), 10,25,50,75,100,150,300,500,700,1000$, 1500 and $2000 \mathrm{~m}$.

\section{Methodologies and instruments}

The hydrological casts were supported by a CTD vertical profile recorded from either EG $+\mathrm{G} \mathrm{Mk} 3$ or ME mod KMS probes. Temperature and depth were

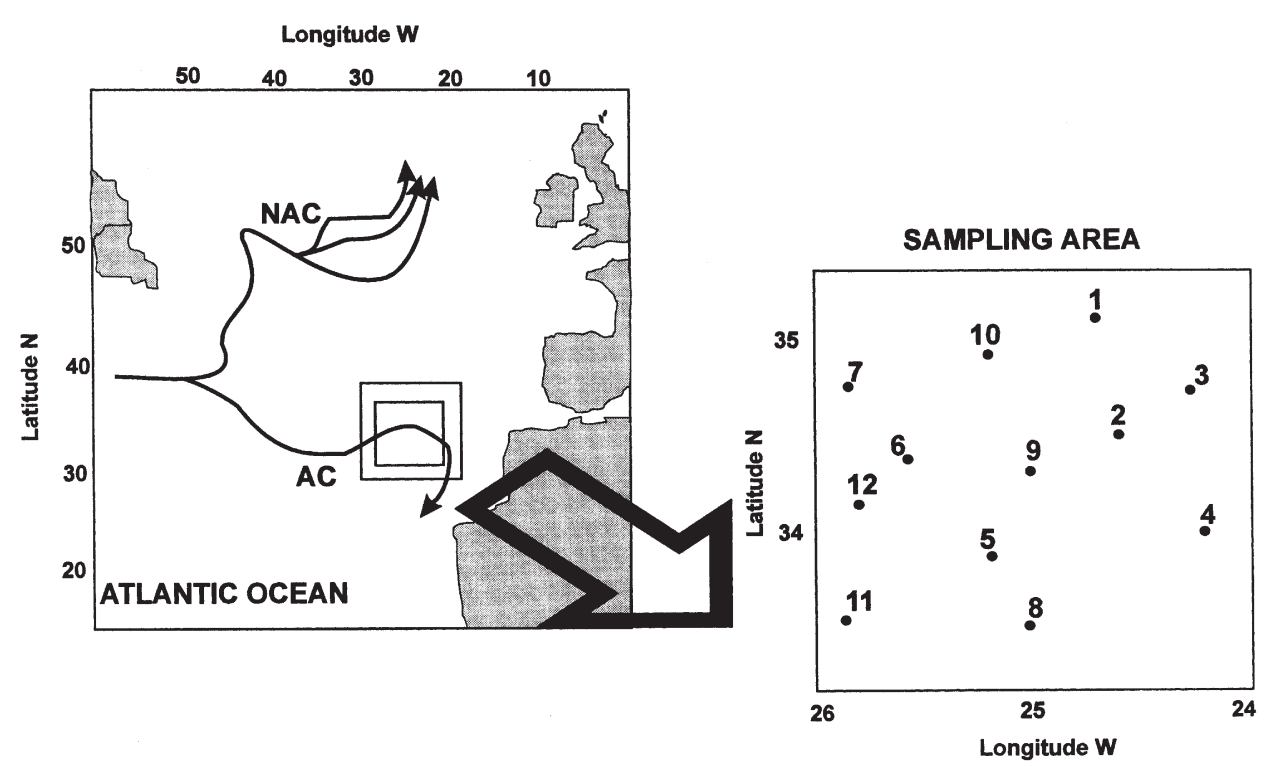

FIG. 1. - The location of sampling stations in the SEMAPHORE area between $33^{\circ} \mathrm{N}-36^{\circ} \mathrm{N}$ and $24^{\circ} \mathrm{W}-26^{\circ} \mathrm{W}$ southwest of Azores (AC: Azores current, NAC: North Atlantic Current). 
checked by means of analogue or SIS digital reversing thermometers and pressure-meters, placed on the Niskin bottles. At the same time, salinity samples were collected at discrete depths to compare continuous vertical profiles with the values obtained by Autosal 8400 Guildline or Minisal 2001 AGE salinometers.

Chemical analysis was carried out on board; nutrients were assessed according to Hansen and Grasshoff (1983) using a Technicon II autoanalyzer.

Water samples (0.5-2.0 1), for particulate organic matter analysis, were prefiltered on $200 \mu \mathrm{m}$ mesh net to retain larger particles and then filtered. Nuclepore filters $(0.4 \mu \mathrm{m}$ pore size $)$ were utilized for chlorophyll-a (Chl-a), phaeopigment (PHAEO), particulate protein (PPRT) and particulate carbohydrate (PCHO) determination, combusted Whatman GF/F filters ( 0.8 $\mu \mathrm{m}$ pore size) were used for organic carbon (POC) and nitrogen (PON) analyses. Filters were then stored at $-20^{\circ} \mathrm{C}$. Since we used different types of filters for the protein (nuclepore) and PON (GF/F) analyses, a problem arised with protein-N to particulate nitrogen ratio (exceeding one). For these reason, we avoid the analysis of the two parameters in a single task or in quantitative terms because it is in our understanding this might probably lead to an uncorrected interpretation of the aliased data. In contrast we only used PPRT and PON data in relation to parameters such as POC, PCHO and Chl-a data for the calculation of the $\mathrm{C} / \mathrm{N}, \mathrm{PPRT} / \mathrm{PCHO}$ and Chl-a:PPRT ratios as tools to assess qualitative aspect of particulate matter. The problem does not arise when using POC and PON versus Chl-a data (such as the use of POC:Chl-a ratios) given the size of phytoplankton cells normally exceeds $0.8 \mu \mathrm{m}$.

Samples were collected on single replicates. However, a series of replicate samples (3 to 5) were collected at different times on surface water in the Canary basin to define the coefficient of variations (C.V.) for the various parameters. C.V.s were: $5.3 \%$ for POC, $5.7 \%$ for PON, $16 \%$ for $\mathrm{PCHO}$ and $8.2 \%$ for PPRT.

Chlorophyll-a and phaeopigment $(90 \%$ acetone extraction) concentrations were determined spectrophotometrically according to Lorenzen and Jeffrey (1980). Phaeopigments were measured after acidification of the supernatant with $0.1 \mathrm{~N} \mathrm{HCl}$. Particulate carbohydrates were measured according to Dubois et al. (1956). D(+)-glucose was used as a standard. Particulate proteins were assessed according to Hartree (1972) with bovine albumine solutions used as standards.
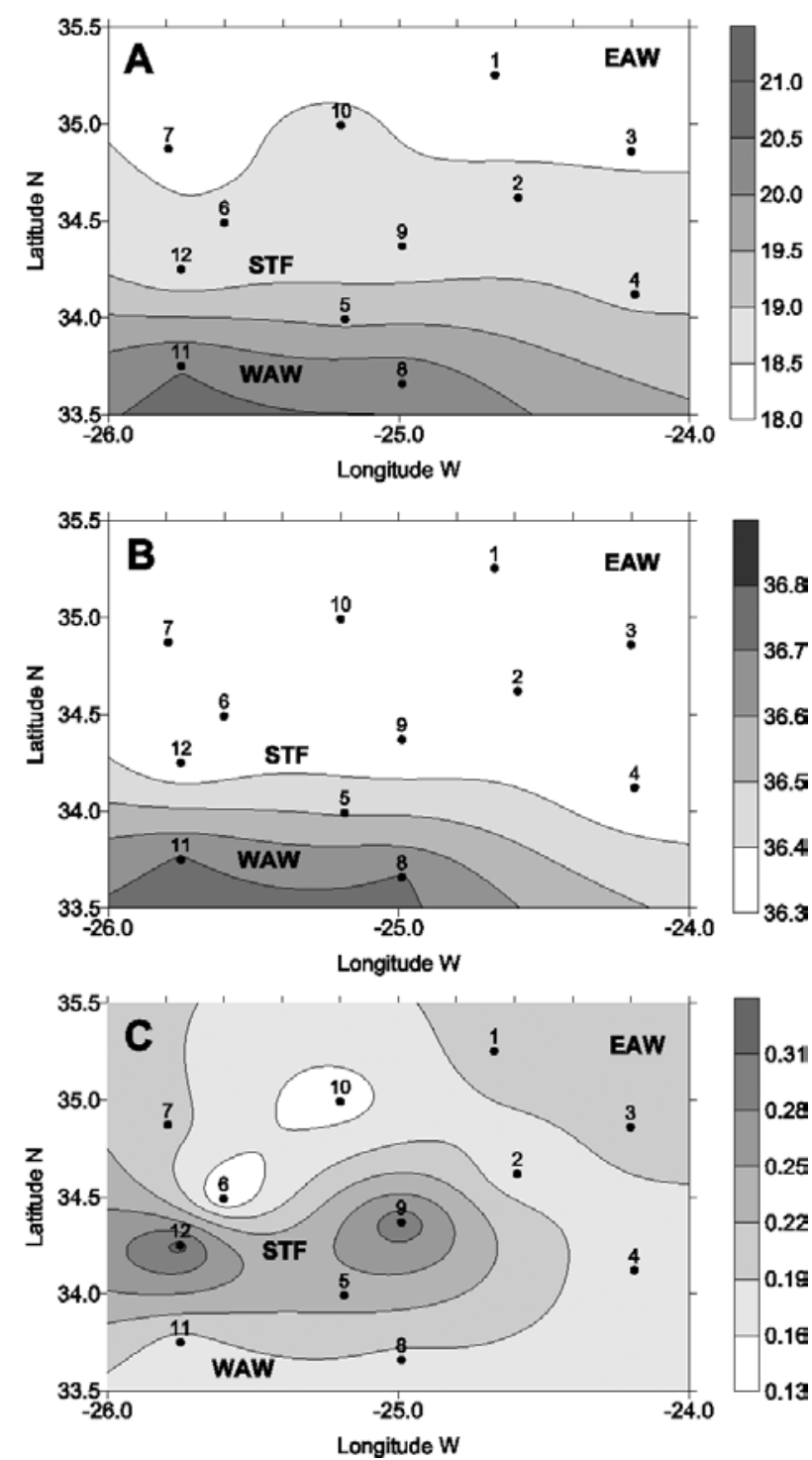

FIG. 2. - Distribution of (a) temperature $\left(\mathrm{C}^{\circ}\right)$, (b) salinity and (c) chlorophyll-a as integrated values in the upper $100 \mathrm{~m}$ (EAW: Eastern Atlantic Water; WAW: Western Atlantic Water). The location of the STF, stations positions and numbers are also indicated.

After removal of carbonates by $\mathrm{HCl}$ vapor in a desiccator (Hedges and Stern, 1984; Tanoue, 1985), particulate organic carbon and nitrogen were analysed by combustion using a CHNS-O EA 1108 Elemental Analyzer (Carlo Erba). Cyclohexanone was used as a standard.

\section{RESULTS}

\section{Physical-chemical structure of the STF-AC sys- tem in June 1993}

The subtropical front in June 1993 in the AzoresMadeira region was located between $33^{\circ} \mathrm{N}-36^{\circ} \mathrm{N}$ 


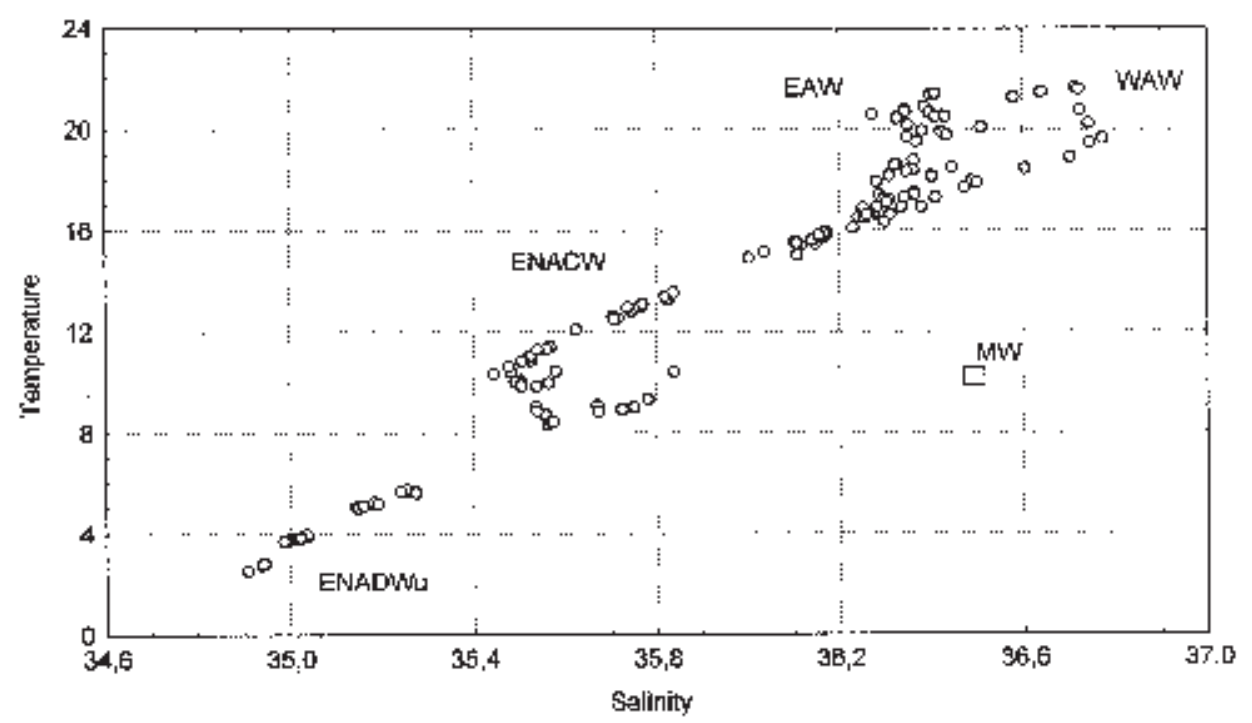

FIG. 3. - T-S diagram showing different water masses present in the area according to Tychensky (1998) (EAW: Eastern Atlantic Water; WAW: Western Atlantic Water; ENACW: Eastern North Atlantic Central Water; MW: Mediterranean Water, ENADWu: upper Eastern North Atlantic Deep Water).

and $24^{\circ} \mathrm{W}-26^{\circ} \mathrm{W}$ separating warmer more saline WAW from colder and fresher EAW (Tychensky, 1998). On the base of the temperature (T) and salinity (S) records four groups of stations were identified: sta. 8 and 11 showing the highest surface $\mathrm{T}$ and $\mathrm{S}$ values $\left(0-100 \mathrm{~m}\right.$ mean integrated values $>20.4^{\circ} \mathrm{C}$ and $>36.7$ ) were defined as WAW stations; sta. 10, 2 , 1,3 showing the lowest surface $\mathrm{T}$ and $\mathrm{S}$ values $(0-$ $100 \mathrm{~m}$ mean integrated values $<18.7^{\circ} \mathrm{C}$ and $<36.4$ ) were defined as EAW stations; sta. 9, 12 were identified as the frontal stations (STF) (Tychensky, 1998). Finally the remaining stations (sta. 4, 5, 6, 7) were identified as transitional between EAW and WAW (Fig. 2a, b). According to the fine-scale physical structure of the STF described by Tychensky (1998), the frontal line has been further highlighted by the highest $0-100 \mathrm{~m}$ integrated chlorophyll-a concentrations as shown in Figure 2c.

Mediterranean Water (MW), which propagates to the south and southwest and crosses the Azores area, has been shown to cause relatively strong temperature and salinity (T-S) anomalies, leading to some dispersion in the T-S water mass diagram (Tychensky, 1998). Below the thermocline (0-100 m) the TS diagram as well as temperature and salinity profiles highlight the presence of a tongue of salt water (35.6 isohaline) arising from the influence of Mediterranean water at a depth of $\sim 1000 \mathrm{~m}$ (Fig. 3). At greater depths, we found the upper part of North East Atlantic Deep Water (NEADWu), showing a range of temperatures and salinities values of $3{ }^{\circ} \mathrm{C}$ $6^{\circ} \mathrm{C}$ and 34.9-35.3 respectively.

TABLE 1. - Vertical distribution of chemical-physical parameters as mean values $( \pm$ std) for WAW, STF and EAW stations respectively (reported are: temperature $(\mathrm{T})$, salinity $(\mathrm{S})$, nitrate $\left(\mathrm{NO}_{3}^{-}\right)$and phosphate $\left(\mathrm{PO}_{4}^{3-}\right)$ ).

\begin{tabular}{|c|c|c|c|c|c|c|c|c|c|c|c|c|}
\hline \multicolumn{2}{|c|}{ Depth (m) } & \multicolumn{2}{|l|}{$\mathrm{T}\left({ }^{\circ} \mathrm{C}\right)$} & \multicolumn{3}{|c|}{$\mathrm{S}(\% \circ)$} & \multicolumn{3}{|c|}{$\mathrm{NO}_{2}^{-}\left(\right.$umol l $\left.^{-1}\right)$} & \multicolumn{3}{|c|}{$\mathrm{PO}^{3-}\left(\right.$ umol l $\left.^{-1}\right)$} \\
\hline$\downarrow$ & WAW & STF & EAW & WAW & STF & EAW & WAW & STF & EAW & WAW & STF & EAW \\
\hline 0 & $21.6 \pm 0.1$ & $21.4 \pm 0.0$ & $20.3 \pm 0.4$ & $36.7 \pm 0.1$ & $36.4 \pm 0.0$ & $36.4 \pm 0.0$ & $0.07 \pm 0.02$ & $0.07 \pm 0.02$ & $0.07 \pm 0.06$ & $0.02 \pm 0.00$ & $0.02 \pm 0.01$ & $0.03 \pm 0.00$ \\
\hline 25 & $21.6 \pm 0.1$ & $20.3 \pm 0.2$ & $20.1 \pm 0.5$ & $36.7 \pm 0.1$ & $36.3 \pm 0.0$ & $36.4 \pm 0.0$ & $0.03 \pm 0.00$ & $0.03 \pm 0.00$ & $0.03 \pm 0.01$ & $0.01 \pm 0.01$ & $0.00 \pm 0.01$ & $0.04 \pm 0.02$ \\
\hline 50 & $20.5 \pm 0.4$ & $18.1 \pm 0.2$ & $18.3 \pm 0.5$ & $36.7 \pm 0.0$ & $36.3 \pm 0.0$ & $36.4 \pm 0.1$ & $0.03 \pm 0.02$ & $0.03 \pm 0.00$ & $0.01 \pm 0.01$ & $0.01 \pm 0.02$ & $0.01 \pm 0.01$ & $0.03 \pm 0.02$ \\
\hline 75 & $19.6 \pm 0.1$ & $17.1 \pm 0.1$ & $17.1 \pm 0.2$ & $36.8 \pm 0.0$ & $36.3 \pm 0.0$ & $36.3 \pm 0.1$ & $0.04 \pm 0.02$ & $0.15 \pm 0.17$ & $0.01 \pm 0.01$ & $0.02 \pm 0.02$ & $0.01 \pm 0.02$ & $0.04 \pm 0.02$ \\
\hline 100 & $18.7 \pm 0.3$ & $16.6 \pm 0.1$ & nd & $36.7 \pm 0.1$ & $36.3 \pm 0.0$ & nd & $0.26 \pm 0.23$ & $1.34 \pm 0.98$ & $0.82 \pm 0.72$ & $0.04 \pm 0.04$ & $0.10 \pm 0.01$ & $0.07 \pm 0.04$ \\
\hline 150 & $17.6 \pm 0.4$ & $15.7 \pm 0.2$ & $15.5 \pm 0.3$ & $36.5 \pm 0.1$ & $36.1 \pm 0.0$ & $36.1 \pm 0.0$ & $2.60 \pm 0.77$ & $2.86 \pm 1.36$ & $2.50 \pm 0.72$ & $0.12 \pm 0.03$ & $0.17 \pm 0.06$ & $0.18 \pm 0.03$ \\
\hline 300 & $15.4 \pm 0.7$ & $13.3 \pm 0.3$ & $12.9 \pm 0.3$ & $36.1 \pm 0.1$ & $35.8 \pm 0.0$ & $35.8 \pm 0.0$ & $5.63 \pm 1.18$ & $7.33 \pm 0.41$ & $7.56 \pm 0.52$ & $0.35 \pm 0.09$ & $0.51 \pm 0.03$ & $0.57 \pm 0.04$ \\
\hline 500 & $12.6 \pm 0.1$ & $11.2 \pm 0.2$ & $11.0 \pm 0.3$ & $35.7 \pm 0.0$ & $35.5 \pm 0.0$ & $35.5 \pm 0.0$ & $14.15 \pm 0.32$ & $15.54 \pm 0.23$ & $15.51 \pm 0.31$ & $0.59 \pm 0.05$ & $0.82 \pm 0.04$ & $0.87 \pm 0.08$ \\
\hline 700 & $10.5 \pm 0.2$ & $9.9 \pm 0.0$ & $10.1 \pm 0.3$ & $35.5 \pm 0.0$ & $35.5 \pm 0.0$ & $35.6 \pm 0.2$ & $16.07 \pm 0.19$ & $16.27 \pm 0.42$ & $16.41 \pm 0.16$ & $0.92 \pm 0.02$ & $0.97 \pm 0.05$ & $1.01 \pm 0.05$ \\
\hline 1000 & $9.0 \pm 0.1$ & $8.4 \pm 0.0$ & $9.0 \pm 0.2$ & $35.5 \pm 0.0$ & $35.6 \pm 0.0$ & $35.7 \pm 0.0$ & $16.66 \pm$ nd & $16.55 \pm 0.03$ & $16.49 \pm 0.07$ & $0.91 \pm 0.23$ & $1.04 \pm 0.01$ & $1.04 \pm 0.00$ \\
\hline 1500 & $5.7 \pm 0.1$ & $5.1 \pm 0.1$ & $5.2 \pm 0.1$ & $35.2 \pm 0.0$ & $35.2 \pm 0.0$ & $35.2 \pm 0.0$ & $16.49 \pm 0.06$ & $16.49 \pm 0.03$ & $16.53 \pm 0.04$ & $1.06 \pm 0.01$ & $1.07 \pm 0.01$ & $1.09 \pm 0.02$ \\
\hline 2000 & $2.8 \pm 0.0$ & $3.3 \pm 0.8$ & $3.6 \pm 0.5$ & $34.9 \pm 0.0$ & $35.0 \pm 0.1$ & $35.0 \pm 0.0$ & $17.16 \pm$ nd & $16.80 \pm 0.42$ & $16.51 \pm 0.55$ & $1.01 \pm 0.37$ & $1.13 \pm 0.12$ & $1.20 \pm 0.16$ \\
\hline
\end{tabular}

nd=not determined 
TABLE 2. - Vertical distribution of biochemical parameters as mean values ( \pm std) for WAW, STF and EAW stations respectively (reported are: particulate organic carbon (POC), particulate organic nitrogen (PON), particulate proteins (PPRT), particulate carbohydrates (PCHO), chlorophyll-a (CHL-a) and phaeopigments (PHAEO)).

\begin{tabular}{|c|c|c|c|c|c|c|c|c|c|}
\hline \multirow[t]{2}{*}{ Depth (m) } & \multicolumn{3}{|c|}{$\mathrm{POC}\left(\mu \mathrm{gC} 1^{-1}\right)$} & \multicolumn{3}{|c|}{ PON $\left(\mu g N 1^{-1}\right)$} & \multicolumn{3}{|c|}{ PPRT $\left(\mu \mathrm{g} \mathrm{l}^{-1}\right)$} \\
\hline & WAW & STF & EAW & WAW & STF & EAW & WAW & STF & EAW \\
\hline 0 & $35.9 \pm 12.9$ & $45.9 \pm 2.2$ & $41.0 \pm 4.1$ & $5.0 \pm 0.0$ & $6.1 \pm 1.2$ & $5.3 \pm 0.8$ & $36.9 \pm 3.9$ & $38.7 \pm 3.9$ & $37.2 \pm 7.9$ \\
\hline 25 & $42.4 \pm 5.1$ & $50.4 \pm 1.1$ & $42.9 \pm 2.6$ & $5.2 \pm 0.4$ & $6.1 \pm 0.6$ & $6.0 \pm 1.0$ & $38.2 \pm 0.5$ & $38.6 \pm 7.8$ & $40.6 \pm 8.4$ \\
\hline 50 & $41.1 \pm 3.9$ & $53.9 \pm 12.6$ & $49.0 \pm 8.2$ & $5.2 \pm 0.2$ & $6.9 \pm 1.1$ & $6.2 \pm 1.1$ & $35.4 \pm 1.5$ & $43.2 \pm 1.7$ & $38.5 \pm 4.4$ \\
\hline 75 & $36.7 \pm 3.1$ & $55.6 \pm 3.2$ & $45.7 \pm 8.1$ & $5.7 \pm 1.1$ & $8.3 \pm 0.7$ & $6.3 \pm 1.8$ & $31.1 \pm 0.2$ & $51.9 \pm 9.5$ & $46.2 \pm 13.2$ \\
\hline 100 & $44.6 \pm 0.9$ & $33.7 \pm 2.0$ & $43.3 \pm 8.4$ & $6.4 \pm 0.3$ & $4.4 \pm 0.3$ & $5.8 \pm 2.0$ & $39.0 \pm 4.6$ & $30.2 \pm 2.8$ & $39.0 \pm 10.1$ \\
\hline 150 & nd & $25.5 \pm 7.6$ & $25.9 \pm 5.9$ & nd & $2.6 \pm 0.5$ & $2.7 \pm 1.2$ & $33.7 \pm 8.2$ & $20.2 \pm 2.6$ & $23.2 \pm 2.6$ \\
\hline 300 & $21.1 \pm 5.8$ & $18.7 \pm 4.8$ & $24.8 \pm 8.2$ & $2.8 \pm 1.0$ & $2.5 \pm 0.7$ & $3.2 \pm 1.6$ & $25.4 \pm 0.5$ & $21.0 \pm 4.1$ & $21.9 \pm 2.8$ \\
\hline 500 & $23.6 \pm 9.9$ & $15.9 \pm 3.9$ & $20.7 \pm 4.4$ & $2.9 \pm 1.6$ & $2.2 \pm 0.6$ & $3.0 \pm 1.3$ & $20.2 \pm 4.9$ & $20.6 \pm 6.0$ & $17.7 \pm 6.7$ \\
\hline 700 & $14.3 \pm 4.7$ & $18.5 \pm 5.9$ & $17.6 \pm 3.3$ & $1.9 \pm 0.0$ & $2.4 \pm 0.1$ & $2.3 \pm 1.1$ & $19.9 \pm 3.3$ & $18.9 \pm 4.5$ & $29.4 \pm 11.0$ \\
\hline 1000 & $18.3 \pm 2.1$ & $21.5 \pm 5.7$ & $17.5 \pm 6.7$ & $1.9 \pm 0.1$ & $2.7 \pm 0.2$ & $2.1 \pm 1.1$ & $21.6 \pm 5.2$ & $24.6 \pm 1.2$ & $16.2 \pm 6.9$ \\
\hline 1500 & $20.5 \pm 4.0$ & $20.8 \pm 3.9$ & $20.5 \pm 8.4$ & $2.4 \pm 0.5$ & $2.4 \pm 0.2$ & $2.5 \pm 1.3$ & $28.5 \pm 17.7$ & $28.6 \pm 1.1$ & $25.3 \pm 11.2$ \\
\hline \multirow[t]{3}{*}{2000} & $22.1 \pm 5.0$ & $28.0 \pm 7.6$ & $20.1 \pm 11.5$ & $2.1 \pm 0.2$ & $3.8 \pm 2.1$ & $2.2 \pm 1.5$ & $28.9 \pm 7.2$ & $20.2 \pm 0.4$ & $17.0 \pm 3.1$ \\
\hline & \multicolumn{3}{|c|}{ PCHO $\left(\mu \mathrm{g} \mathrm{l}^{-1}\right)$} & \multicolumn{3}{|c|}{ CHL-a $\left(\mu \mathrm{g} \mathrm{l}^{-1}\right)$} & \multicolumn{3}{|c|}{ PHAEO $\left(\mu \mathrm{g} \mathrm{l}^{-1}\right)$} \\
\hline & WAW & STF & EAW & WAW & STF & EAW & WAW & STF & EAW \\
\hline 0 & $22.2 \pm \mathrm{nd}$ & $27.3 \pm \mathrm{nd}$ & $26.0 \pm 17.5$ & $0.1 \pm 0.0$ & $0.1 \pm 0.0$ & $0.1 \pm 0.0$ & $0.0 \pm 0.0$ & $0.0 \pm 0.0$ & $0.0 \pm 0.0$ \\
\hline 25 & $17.6 \pm$ nd & $28.8 \pm$ nd & $20.2 \pm 4.3$ & $0.1 \pm 0.0$ & $0.1 \pm 0.0$ & $0.1 \pm 0.0$ & $0.0 \pm 0.0$ & $0.0 \pm 0.0$ & $0.0 \pm 0.0$ \\
\hline 50 & $18.7 \pm \mathrm{nd}$ & $24.4 \pm$ nd & $27.6 \pm 3.1$ & $0.1 \pm 0.0$ & $0.2 \pm 0.1$ & $0.1 \pm 0.0$ & $0.0 \pm 0.0$ & $0.1 \pm 0.0$ & $0.0 \pm 0.0$ \\
\hline 75 & $17.3 \pm \mathrm{nd}$ & $18.6 \pm$ nd & $17.5 \pm 3.8$ & $0.2 \pm 0.0$ & $0.8 \pm 0.1$ & $0.3 \pm 0.1$ & $0.1 \pm 0.0$ & $0.3 \pm 0.0$ & $0.2 \pm 0.1$ \\
\hline 100 & $12.5 \pm \mathrm{nd}$ & $13.7 \pm$ nd & $17.0 \pm 1.6$ & $0.5 \pm 0.0$ & $0.2 \pm 0.1$ & $0.4 \pm 0.1$ & $0.2 \pm 0.1$ & $0.2 \pm 0.0$ & $0.3 \pm 0.0$ \\
\hline 150 & $14.4 \pm$ nd & $5.2 \pm$ nd & $11.5 \pm 3.0$ & $0.1 \pm 0.1$ & $0.0 \pm 0.0$ & $0.1 \pm 0.1$ & $0.1 \pm 0.1$ & $0.1 \pm 0.0$ & $0.1 \pm 0.0$ \\
\hline 300 & $11.0 \pm$ nd & $7.0 \pm$ nd & $10.5 \pm 1.9$ & nd & nd & nd & nd & nd & nd \\
\hline 500 & $11.1 \pm$ nd & $4.8 \pm$ nd & $6.0 \pm 3.5$ & nd & nd & nd & nd & nd & nd \\
\hline 700 & $14.7 \pm$ nd & $7.0 \pm$ nd & $6.0 \pm 1.6$ & nd & nd & nd & nd & nd & nd \\
\hline 1000 & $8.6 \pm$ nd & $4.0 \pm \mathrm{nd}$ & $9.1 \pm 2.7$ & nd & nd & nd & nd & nd & nd \\
\hline 1500 & $15.1 \pm \mathrm{nd}$ & $9.4 \pm$ nd & $4.0 \pm 4.5$ & nd & nd & nd & nd & nd & nd \\
\hline 2000 & $11.3 \pm$ nd & $3.7 \pm$ nd & $4.8 \pm 0 .^{\circ} 7$ & nd & nd & nd & nd & nd & nd \\
\hline
\end{tabular}

Data on physical and chemical parameters for the different water masses are summarized in Table 1 (as previously described selected stations used to average the data were: sta. 8 and 11 for Western Atlantic Water (WAW), sta.10, 2, 1, 3 for Eastern Atlantic Water (EAW) and sta. 9, 12 for the frontal line section (STF)).

Phosphate and nitrate concentrations were almost depleted in the surface layer (upper $100 \mathrm{~m}$ ) and were close to the detection limit $\left(\mathrm{NO}_{3}<0.15\right.$

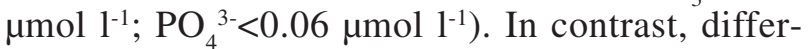
ences in nutrient concentrations became evident at $\sim 500 \mathrm{~m}$ with lower values ranging from 13.9$14.4 \mu \mathrm{mol} \mathrm{l}^{-1}$ for nitrates and $0.5-0.7 \mu \mathrm{mol} \mathrm{l} \mathrm{l}^{-1}$ for phosphates and higher values ranging from 15$15.7 \mu \mathrm{mol} \mathrm{l}^{-1}$ for nitrates and $0.8-1 \mu \mathrm{mol} \mathrm{l}^{-1}$ for phosphates in the WAW and EAW stations, respectively.

Nutrient concentrations increased with increasing depth up to mean values of $16.6 \mu \mathrm{mol} \mathrm{l}^{-1}$ for nitrates and $1.0 \mu \mathrm{mol} \mathrm{l}^{-1}$ for phosphates detected at a depth of $1000 \mathrm{~m}$. From 1000 to $2000 \mathrm{~m}$ depth only a slight increase has been observed for both nitrate and phosphate concentrations.

\section{Biochemical composition of POM in the Azores-Madeira region}

Elemental and biochemical composition of particulate organic matter (POM) was investigated for POC, PON, proteins, carbohydrates and phytopigments in the Azores-Madeira region down to a depth of $2000 \mathrm{~m}$; data on the vertical distribution of biochemical variables for the different water masses are summarized in Table 2. POC and PON vertical profiles on a section crossing the frontal line showed highest surface values at frontal stations (Fig. 4). POC and PON concentrations ranged, in the surface layer, between 23.3-64.5 $\mu \mathrm{gC} \mathrm{l}^{-1}$ and 2.9-9.1 $\mu \mathrm{gN} \mathrm{l}^{-1}$, respectively, and decreased with depth to mean values of $18.5 \mu \mathrm{gC} ~^{-1}$ and $2.3 \mu \mathrm{gN} \mathrm{l}^{-1}$ at $500 \mathrm{~m}$ depth and $16.7 \mu g \mathrm{~g} \mathrm{l}^{-1}$ and $1.9 \mu \mathrm{gN} \mathrm{l}^{-1}$ at $1000 \mathrm{~m}$ depth. No further changes were detected for POC and PON concentrations at greater depths.

A DCM was observed at $\sim 75 \mathrm{~m}$ depth at stations 9 and 12 located on the frontal boundary, and $~ 100$ $m$ depth for the remaining sampling stations (Fig. 5). Chlorophyll-a concentrations in the surface water did not exceed $0.4 \mu \mathrm{g} \mathrm{l}^{-1}$ except at frontal stations 9 

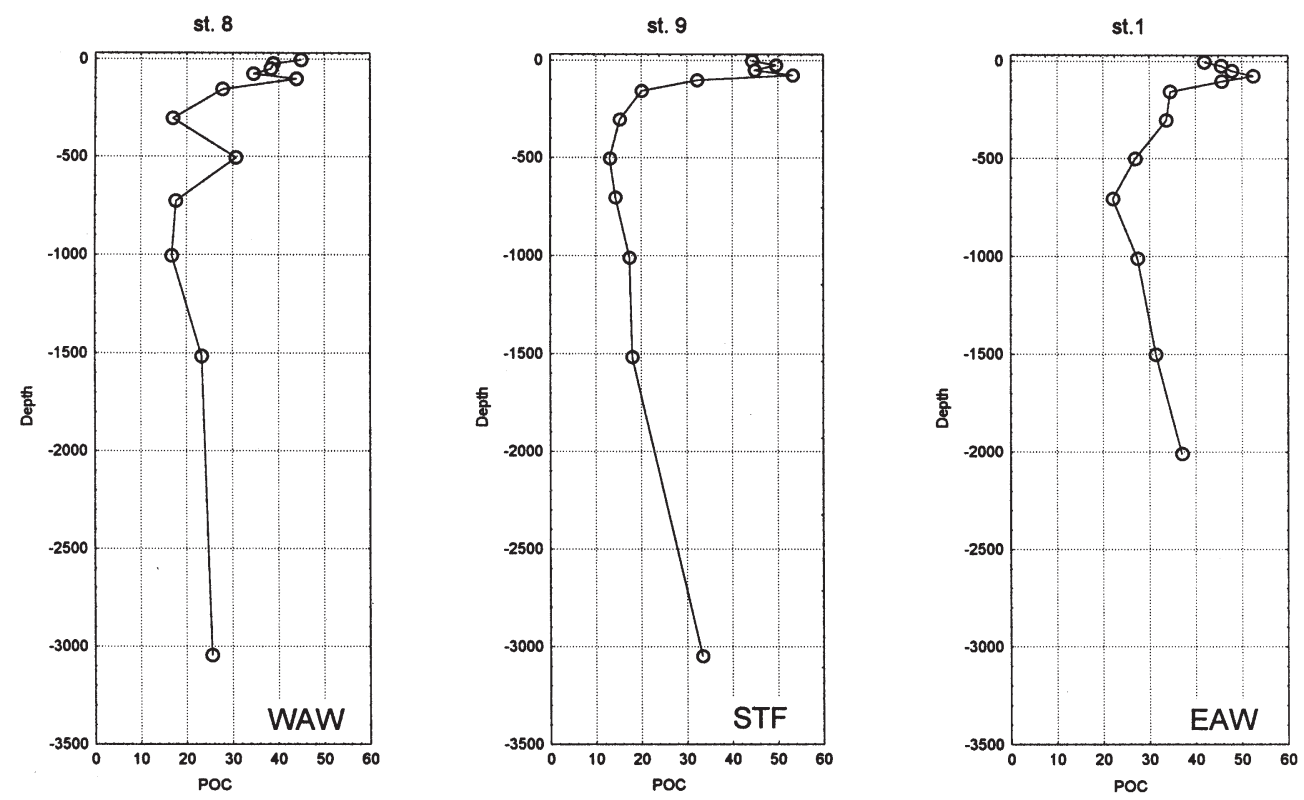

FIG. 4. - Vertical distribution of POC in $\mu \mathrm{gC} 1^{-1}$ for st. 8 (WAW), st.9 (STF) and st.1 (EAW).
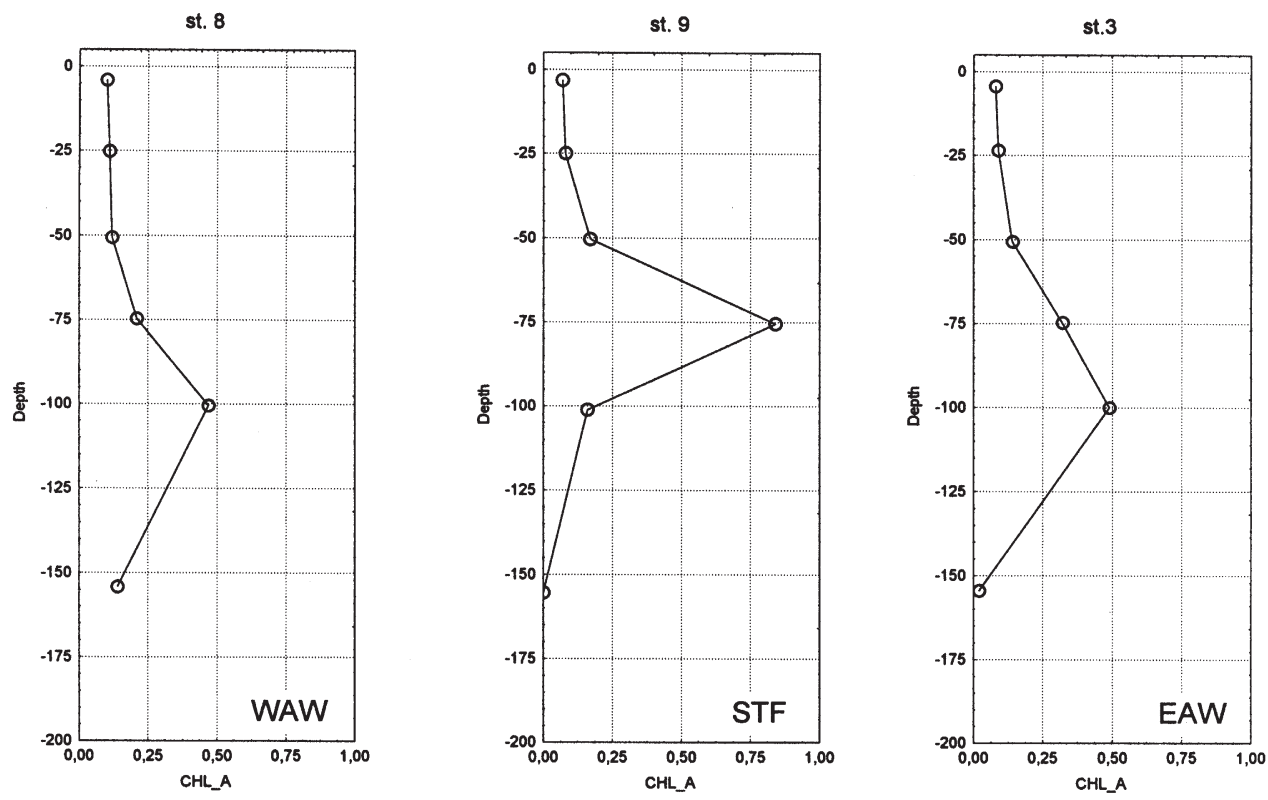

FIG. 5. - Vertical distribution of chlorophyll-a in $\mu$ g $1^{-1}$ for st. 8 (WAW), st.9 (STF) and st.3 (EAW).

and 12 were chlorophyll-a reached $0.8 \mu \mathrm{g} \mathrm{l^{-1 }}$. Phaeopigment values were generally lower than those observed for chlorophyll-a in the surface layer, ranging from 0 (below detection for spectrophotometric analysis) to $0.2 \mu \mathrm{g} \mathrm{l^{-1 }}$.

Particulate proteins and carbohydrates were also very low and were on average $40 \mu \mathrm{g} \mathrm{l}^{-1}$ and $22.2 \mu \mathrm{g} \mathrm{l}^{-1}$ in the surface layer, respectively. As observed for POC and PON, the values decreased with depth, reaching mean concentrations of 19.5 $\mu \mathrm{g}^{-1}$ for proteins and $5.7 \mu \mathrm{g} \mathrm{l^{-1 }}$ for carbohydrates at a depth of $500 \mathrm{~m}$. A further decrease in protein concentrations occurred at a depth of $1000 \mathrm{~m}$, with mean values reaching $18 \mu \mathrm{g}^{-1}$, while carbohydrates increased slightly up to mean concentrations of $7.0 \mu \mathrm{g} \mathrm{1^{-1 }}$.

At greater depths, an increase in protein concentrations also occurred with mean values reaching $25.4 \mu \mathrm{g} \mathrm{l}^{-1}$ and $22.4 \mu \mathrm{g}^{-1}$ at a depth of $1500 \mathrm{~m}$ and $2000 \mathrm{~m}$, respectively. 


\section{DISCUSSION}

In the Canary basin the very low values of POC, PON, nutrients and chlorophyll-a concentrations in the surface layer were in agreement with other studies carried out in the North East Atlantic (Ríos et al., 1995; Pérez et al., 1998; Castro et al., 1998; Hall et al., 2000), and were comparable with values found in other areas of the open ocean such as the North Pacific gyre (Sharp et al., 1980; Eppley et al., 1988), the deep southern Pacific (Fabiano et al., 2000; Povero et al., 2000) and several oligotrophic areas in the Mediterranean Sea (Bethoux et al., 1998; Danovaro et al., 2000). At $1000 \mathrm{~m}$ depth, inorganic nutrients showed higher average values than found in deep layer outflows across the Straits of Gibraltar (Bethoux et al., 1998) and in the Tyrrhenian Sea (Povero et al., 1990); in contrast, POC and PON concentrations were lower in comparison to Mediterranean deep water (Tselepides et al., 2000) and seemed in agreement with the low productivity of this area (Fernandez et al., 1996).

The C:N ratio of the suspended matter in the euphotic zone was higher (mean $\mathrm{C}: \mathrm{N}$ ratio 7.9 ) than some values obtained in the equatorial Atlantic (C:N 6.1; Herbland and le Bouteiller, 1983 ) and in several other oceanic regions (CopinMontegut and Copin Montegut, 1983), suggesting that the particulate matter in our study region was mostly of detrital origin. The particulate material below the euphotic zone in our region had a $\mathrm{C}: \mathrm{N}$ ratio of 7.9-9.4 in the euphotic zone indicating preferential $\mathrm{N}$ removal.

All POC:Chl-a ratios were very high (mean of all surface layers $=363.7$ ) with values double those observed in other oceanic regions such as the equatorial Pacific (Pena et al., 1991), suggesting that the local autotrophic component accounts for a low fraction of POM. In contrast, low values of the
POC:Chl-a ratios has been found in the DCM. The Chl-a:PPRT ratio, which is an indicator of autotrophic/total biomass (Dortch and Packard, 1989) is also highest in the DCM, indicating high autotrophic biomass (refer to the material and methods section for an explanation of the problems arising from the use of different types of filters).

The PPRT:PCHO ratio is employed to characterise the POM biochemical fraction and, to a certain extent, to assess its "age" (Fabiano et al., 1993). The PPRT:PCHO ratio averaged 1.9 in the surface layer with the highest values (up to 3.4) observed at frontal stations in the DCM. The dominance of the proteins as suggested by high PPRT:PCHO ratios are characteristics of highly productive areas such as lagoons (Pusceddu et al., 1996) and estuaries (Navarro et al., 1993), but have also been reported during phytoplankton blooms in oligotrophic areas, such as the Ligurian Sea (Fabiano et al., 1984). However, while the concentrations of chlorophyll-a and particulate proteins decreased with increasing depth in response to grazing activity and decomposition processes, the PPRT:PCHO ratio remained quite high and is sometimes higher in deep water than at the surface. The high PPRT:PCHO ratio found in the deep water, below the thermocline, is in agreement with the "protein enrichment" observed by Fabiano et al. (2001) in fresh detritus, mainly caused by the bacterial colonization of particles due to the low values (about 4) of the bacterial $\mathrm{C}: \mathrm{N}$ ratio (Lee and Fuhrman, 1987). Thus, the persistence of the protein dominance in POM with increasing depth in the Canary Basin may be related to the marked oligotrophy of these waters, where microbial communities may achieve a high importance in the biochemical composition of POM (Cho and Azam, 1988).

During June 1993, the DCM was well established and conversely to what was observed by

TABLE 3. - Mixed layer integrated values (0-100 m) of selected biological variables for WAW, STF and EAW stations.

\begin{tabular}{|c|c|c|c|c|}
\hline Variables & $\begin{array}{l}\text { WAW } \\
(\text { sta } 8,11)\end{array}$ & $\begin{array}{c}\text { STF } \\
\text { (sta 9,12) }\end{array}$ & $\begin{array}{c}\text { EAW } \\
\text { (sta } 10,2,1,3)\end{array}$ & $\begin{array}{c}\text { one-way ANOVA } \\
p \text {-level }\end{array}$ \\
\hline Integrated POC $0-100 \mathrm{~m}\left(\mu \mathrm{gC}^{-1}\right)$ & 40.09 & 49.9 & 44.9 & 0.07 \\
\hline Integrated PON $0-100 \mathrm{~m}\left(\mu \mathrm{gN} ~^{-1}\right)$ & 5.5 & 6.6 & 6.0 & 0.32 \\
\hline Integrated particulate proteins $0-100 \mathrm{~m}\left(\mu \mathrm{g}^{-1}\right)$ & 35.7 & 42.0 & 40.9 & 0.34 \\
\hline Integrated particulate carbohydrates $0-100 \mathrm{~m}\left(\mu \mathrm{g} \mathrm{l}^{-1}\right)$ & 17.7 & 23.1 & 21.7 & 0.55 \\
\hline Integrated $\mathrm{POC} / \mathrm{Chl}-\mathrm{a}$ ratio $0-100 \mathrm{~m}$ & 297.4 & 346.7 & 447.1 & nd \\
\hline Depth of the DCM $(\mathrm{m})$ & 100 & 75 & 100 & nd \\
\hline Chlorophyll-a $\left(\mu \mathrm{g} \mathrm{l}^{-1}\right)$ at the DCM & 0.5 & 0.8 & 0.4 & nd \\
\hline POC/Chl-a ratio at the DCM & 174.8 & 154.1 & 172.5 & nd \\
\hline Chl-a/PPRT ratio at the DCM & 0.013 & 0.015 & 0.010 & nd \\
\hline
\end{tabular}

nd $=$ not detected 
Fasham et al. (1985) it appeared on average $20 \mathrm{~m}$ shallower (DCM depth $=75 \mathrm{~m}$ ) and of greater magnitude $\left(\mathrm{Chl}-\mathrm{a}=0.8 \mu \mathrm{g} \mathrm{l}^{-1}\right)$ at the frontal stations, while no significant differences were evident in its magnitude and depth between WAW and EAW (Fig. 5). A difference has been highlighted in the vertical distribution of POC and PON with higher concentration detected at stations 2, 10, 1 belonging to EAW (Table 2, Fig. 4). In contrast, the lowest values of POC and PON as well as particulate proteins and carbohydrates were found in the WAW.

Statistical analysis was carried out to further define the differences detected in the quantity and quality of POM between EAW and WAW. The regression between POC versus PON was used as a first attempt to investigate such a difference. POC and PON concentrations showed high correlation if calculated for all data but, in agreement with CopinMontegut (1983) in several oceanic areas no significant changes (T-statistics, $\mathrm{p}>0.05$ ) were evident in the slopes and intercepts of the regression lines for the different water types.

On the contrary, the study of mean integrated values of selected biochemical variables in the upper $100 \mathrm{~m}$ highlighted the difference occurring in WAW, EAW as well as frontal stations on the basis of particulate matter composition (Table 3). WAW showed the smallest integrated concentrations of particulate organic carbon, particulate organic nitrogen, particulate proteins and particulate carbohydrates; by contrast frontal stations showed the highest concentrations while EAW stations had intermediate values. All these results coupled with the highest POC:Chla ratio found in EAW suggest a possible delay occurring in the production cycle between the two water masses. Alternatively, the WAW is a more stratified and oligotrophic body of water than is EAW, and it always has lower biomass and nutrients than the more productive EAW. In this case, there may not be a temporal offset but, rather, an annually averaged difference as well.

In conclusion, the differences in quantity and quality of particulate material found between water masses suggest that the analysis of POM can be of great help in determining the state of biological processes occurring in this area; furthermore in agreement with previous investigations (Fernandez and Pingree, 1996) the biological signature associated with the STF-AC system supports the conclusion that carbon fixation within the frontal structure might be of significance for regional carbon budgets of the subtropical northeast Atlantic.

\section{ACKNOWLEDGEMENTS}

The authors would like to acknowledge their debt to the captain and crew of the R/V Alliance, to SACLANTCEN (La Spezia, Italy), and to all those who have been involved with the cruise during ocean experiment. We are particularly grateful to Dr. Vincenzo Saggiomo and Federico Corato (Zoological Station, Naples) for their kind assistance.

\section{REFERENCES}

Angel, M.V. - 1989. Vertical profile of pelagic communities in the vicinity of the Azores Front and their implications to deep-sea ecology. Prog. Oceanogr. 22: 1-46.

Bethoux, J.P., P. Morin, C. Chaumery, O. Connan, Gentili, B. and D. Ruiz-Pino. - 1998. Nutrients in the Mediterranean Sea, mass balance and statistical analysis of concentrations with respect to environmental change. Mar. Chem. 63: 155-169.

Boyd, P.W. and P.P. Newton. - 1999. Does planktonic community structure determine downward particulate organic carbon flux in different oceanic provinces? Deep-Sea Res. 46: 63-91.

Castro, C.G., F.F. Pérez, S.E. Holley and A.F. Ríos. - 1998. Chemical characterisation and modelling of water masses in the Northeast Atlantic. Prog. Oceanogr. 41: 249-279.

Cho, B.C and F. Azam. - 1988. Heterotrophic bacterioplankton production measurement by the tritiated thymidine incorporation method. Archiv. Fur Hydrobiologie Beihft. 31: 153-162.

Copin-Montegut, C. and G. Copin-Montegut. - 1983. Stoichiometry of carbon, nitrogen, and phosphorus in marine particulate matter. Deep-Sea Res. 30: 31-46.

Danovaro, R., A. Dell'Anno, A. Pusceddu, D. Marrale, N. Della Croce, M. Fabiano and A. Tselepides. - 2000. Biochemical composition of pico-, nano- and micro-particulate organic matter and bacterioplankton biomass in the oligotrophic Cretan Sea (NE Mediterranean). Prog. Oceanogr. 46: 279-310.

Dortch, Q. and T.T. Packard. -1989. Differences in biomass structure between oligotrophic and eutrophic marine ecosystems. Deep-Sea Res. 36: 233-240.

Dubois, M., K. Gilles, J.K. Hamilton, P.A. Rebers and F. Smith. 1956. Colorimetric method for determination of sugars and related substances. Anal. Chem. 28: 350-356.

Eppley, R.W. and B.J. Peterson. - 1979. The flux of particulate matter to the deep ocean. Nature, 282: 677-680.

Eppley, R.W., E. Swift, D.G. Redalje, M.R. Landry and L.W. Haas. - 1988. Subsurface chlorophyll maximum in August-September 1985 in the CLIMAX area of the North Pacific. Mar. Ecol. Progr. Ser. 42: 289-301.

Fabiano, M., M. Zavattarelli and S. Palmero. - 1984. Observations sur la matiere organique particularie an Mer Ligure (chlorophylle, proteines, glucides, lipides). Thetys, 11: 133-140.

Fabiano, M., P. Povero and R. Danovaro. - 1993. Distribution and composition of the particulate organic matter of the Ross Sea (Antarctica). Polar Biol. 13: 525-533.

Fabiano, M. and A. Pusceddu. - 1998. Total and hydrolizable particulate organic matter (carbohydrates, proteins and lipids) at a coastal station in Terra Nova Bay (Ross Sea, Antarctica). Polar Biol. 19: 125-132.

Fabiano, M., P. Povero and C. Misic. - 2000. Spatial and temporal distribution of particulate organic matter in the Ross Sea. In Ross Sea Ecology, Springer-Verlag, 11: 135-149.

Fabiano, M., C. Misic, E. Manini, R. Danovaro, P. Povero and S. Chiatti. - 2001. Distribution and biochemical composition of suspended and sedimentary organic matter in the Northern Adriatic. In: F.M. Faranda, L. Guglielmo, G. Spezie (eds), Structure and Processes in the Mediterranean Ecosystems. Springer Verlag, 57, pp. 447-454.

Fasham, M.J.R., T. Platt, B. Irwin and K. Jones. - 1985. Factors affecting the spatial pattern of the deep chlorophyll maximum in the region of the Azores front. Progr. Oceanogr. 14: $129-165$. 
Fernández, E. and R.D. Pingree. - 1996. Coupling between physical and biological fields in the North Atlantic subtropical front southeast of the Azores. Deep-Sea Res. 43: 1369-1393.

Fichez, R. - 1991. Suspended particulate organic matter in a Mediterranean submarine cave. Mar. Biol. 108: 167-174.

Gordon, D.C. - 1970. Some studies on the distribution and composition of particulate organic carbon. Deep-Sea Res. 13: 413425 .

Gould, W.J. - 1985. Physical oceanography of the Azores front, Progr. Oceanogr. 14: 167-190.

Hall, I.R., S. Schmidt, I.N. McCave and J.L. Reyss. - 2000. Particulate matter distribution and ${ }^{234} \mathrm{Th} /{ }^{238} \mathrm{U}$ disequilibrium along the Northern Iberian Margin: implications for particulate organic carbon export. Deep-Sea Res. 47: 557-582.

Hansen, H.P. and M. Grasshoff. - 1983. Automated chemical analysis. In: K. Grasshoff, M. Ehrhardt and K. Kremling, (eds.), Methods of seawater analysis, $2^{\text {nd }}$ edition, pp. 347-379. Verlag Chemie, Weinheim.

Hartree, E.F. - 1972. Determination of proteins: a modification of the Lowry methods that give a linear photometric response. Anal. Biochem. 48: 422-427.

Hedges, J.I. and J.H. Stern. - 1984. Carbon and nitrogen determination of carbonate-containing solids. Limnol. Oceanogr. 29: 657-663.

Heilmann, J., K. Richardson and G. Artebjerg. - 1994. Annual distribution and activity of phytoplankton in the Skagerrak/Kattegat frontal region. Mar. Ecol. Progr. Ser. 112: 213-223.

Herbland, A. and A. Le Bouteiller. - 1983. Dynamique du phytoplanctont matiere organique particulaire dans le zone euphotique de l'Atlantique Equatorial. Mar. Biol. 72: 265-278.

Hitchcock, G.L., A.J. Mariano and G. Rossby. - 1993. Mesoscale pigment fields in the Gulf Stream: observation in a meander crest and trough. J. Geophys. Res. 98: 8425-8445.

Holligan, P.M., R.P. Harris, R.C. Newell, D.S. Harbour, R.N. Head, E.A.S. Linley, M.I. Lucas, P.R.G. Tranter, and C.M. Weekley. - 1984. Vertical distribution and portioning of organic carbon in mixing, frontal and stratified waters of the English channel. Mar. Ecol. Progr. Ser. 14:111-127.

Houghton, R.W. and J. Marra. - 1983. Physical/biological structure and exchange across the thermoaline shelf/slope front in the New York bight. J. Geophys. Res. 88: 4467-4481.

Jahnke, R.A. - 1996. The global ocean flux of particulate organic carbon: areal distribution and magnitude. Global Biogeochem. Cycl., 10: 71-88.

Kase, R.H. and G. Siedler. - 1982. Meandering of the subtropical front southeast of the Azores. Nature, 300: 245-246.

Kase, R.H., W. Zenk, T.B. Sanford and W. Hiller. - 1985. Currents, fronts and eddy fluxes in the Canary basin. Progr. Oceanogr. 14: 231-257.

Kawase, M. and J.L. Sarmiento. - 1986. Circulation and nutrients in mid depth Atlantic waters. J. Geophys. Res. 91: C8, 97399748 .

Kiorboe, T., P. Munk, K. Richardson, V. Christensen and H. Paulsen. - 1988. Plankton dynamics and larval herring growth, drift and survival in a frontal area. Mar. Ecol. Progr. Ser. 44:205-219.

Körtzinger, A., W. Koeve, P. Kähler and L. Mintrop. - 2001. C : N ratios in the mixed layer during the productive season in the northeast Atlantic Ocean, Deep-Sea Res. 48: 661-688.

Legendre, L.S., S. Demers and D. Lefaivre. - 1986. Biological production in the marine ergocline. In : J.C.J. Nihoul (ed.), Marine interfaces ecohydrodynamics, pp. 1-29. Elsevier, Amsterdam.

Lee, S. and J.A. Furhman. - 1987. Relationships between biovolume and biomass of naturally derived marine bacterioplankton. Appl. Environ. Microb. 53: 1298-1303.

Levitus, S. - 1982. Climatological atlas of the world ocean, NOAA Tech. Pap., 3, 173 pp.

Lindley, J.A. and R. Williams. - 1994. Relating plankton assemblages to environmental variables using instruments towed by ships-of-opportunity. Mar. Ecol. Progr. Ser. 107:245-262.

Lohrenz, S.E., J.J. Cullen, D.A. Phynney, D.B. Olson and C.S. Yentsch. - 1993. Distribution of pigments and primary produc- tion in a Gulf stream meander. J. Geophys. Res. 98: 1454514560.

Lorenzen, C.J. and S.W. Jeffrey. - 1980. Determination of chlorophyll and phaeopigments spectrophotometric equations. Lim nol. Oceanogr. 12: 343-346.

Menzel, D. - 1967. Particulate organic carbon in the deep sea Deep-Sea Res. 14: 229-238.

Navarro, J.M., E. Clasing, G. Urrutia, G. Asencio, R. Stead, and C. Herrera. - 1993. Biochemical composition and nutritive value of suspended particulate matter over a tidal flat of Southern Chile. Estuar. Coast. Shelf S. 37: 59-73.

Pak, H., D.A. Kiefer and J.C. Kitchen. - 1988. Meridional variations in the concentration of chlorophyll and micro particles in the North Pacific Ocean. Deep-Sea Res. 35: 1151-1171.

Pena, M.A., M.R. Lewis and W.G. Harrison. - 1991. Particulate organic matter and chlorophyll in the surface layer of the equatorial Pacific Ocean along $135^{\circ}$ W. Mar. Ecol. Progr. Ser. $72: 179-188$

Pérez, F.F., A.F. Ríos, C.G Castro and F. Fraga. - 1998- Mixing analysis of nutrients, oxygen and dissolved inorganic carbon in the upper and middle North Atlantic ocean east of the Azores, J. Mar. Syst. 16: 219-233.

Pollard R.T, M.J. Griffiths, S.A. Cunningham, J.F. Read, F.F Pérez and A.F. Ríos. - 1996. Vivaldi 1991 - A study of the formation, circulation and ventilation of Eastern North Atlantic Central Water. Progr. Oceanogr. 37: 167-192.

Poulet, S.A, D. Cossa and J.C. Marty. - 1986. Combined analysis of the size spectra and biochemical composition of particles in the St Lawerence estuary. Mar. Ecol. Progr. Ser. 30:205-214.

Pusceddu, A., E. Serra, O. Sanna and M. Fabiano. - 1996. Seasonal fluctuations in the nutritional value of particulate organic matter in a lagoon. Chem. Ecol. 12:199-212.

Povero, P., T.S. Hopkins and M. Fabiano. - 1990. Oxygen and nutrient observations in the southern Tyrrhenian Sea. Oceanol. Acta. 13: 299-305

Povero, P., M. Fabiano and G. Catalano. - 2000. Particulate organic matter and nutrient utilization in the mixed layer of the Ross Sea. Ross Sea Ecol. 154: 121-134.

Riegman, R., H. Malschaert and F. Colijn. - 1990. Primary production of phytoplankton at a frontal zone located at the northern slope of the Dogger Bank (North Sea). Mar. Biol. 105: 329-336.

Ríos, A.F, T.R. Anderson and F.F. Pérez. - 1995. The carbonic system distribution and fluxes in the NE Atlantic during Spring 1991. Progr. Oceanogr. 35: 295-314.

Sharp, J.H., M.J. Perry, E.H. Renger and R.W. Eppley. - 1980. Phytoplankton rate processes in the oligotrophic waters of the central North Pacific Ocean. J. Plankton Res. 2: 335-353.

Sverdrup, H.V., M.W. Johnson and R.H. Fleming. - 1942. The oceans, their physics, chemistry and general biology. Prentice Hall, New York, 1087 pp.

Sy, A. - 1988. Investigation of large scale circulation patterns in the central North Atlantic: the North Atlantic Current, the Azores Current, and the Mediterranean Water plume in the area of the Mid-Atlantic Ridge. Deep-Sea Res. 35: 383-413.

Tanoue, E. - 1985. Distribution and chemical composition of particulate organic matter in the Pacific sector of the Antarctic Ocean. Trans. Tokyo Univ. Fish., 6: 43-57.

Tychensky, A. -1998. Large structures and temporal change in the Azores Font during the SEMAPHORE experiment. J. Geophys. Res. 103: 25,009-25,027.

Tselepides, A., V. Zervakis, T. Polychronaki, R. Danovaro and G. Chronis. - 2000. Distribution of nutrients and particulate organic matter in relation to the prevailing hydrographic features of the Cretan Sea (NE Mediterranean), Progr. Oceanogr. 46: 113142 .

Wankersky, P.J. and Gordon, Jr. - 1965. Particulate carbonate, organic carbon and $\mathrm{Mn}^{2+}$ in the open ocean. Limnol. Oceanogr. 10: $544-550$

Worthington. - 1976. On the North Atlantic circulation, Johns Hopkins Univ. Stud. Oceanogr., 6: 1-110.

Scient. ed.: L.A. Codispoti 